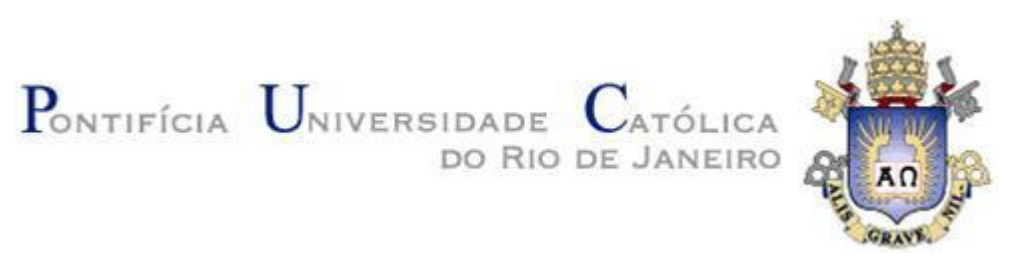

Chantal Intrator

\title{
Using Scripts to Improve Web Accessibility
}

\section{Dissertação de Mestrado}

Dissertation presented to the Postgraduate Program in Informatics of the Departamento de Informática, PUC-Rio as partial fulfillment of the requirements for the degree of Mestre em Informática

Advisor: Prof ${ }^{a}$. Clarisse Sieckenius de Souza

Rio de Janeiro

July 2009 


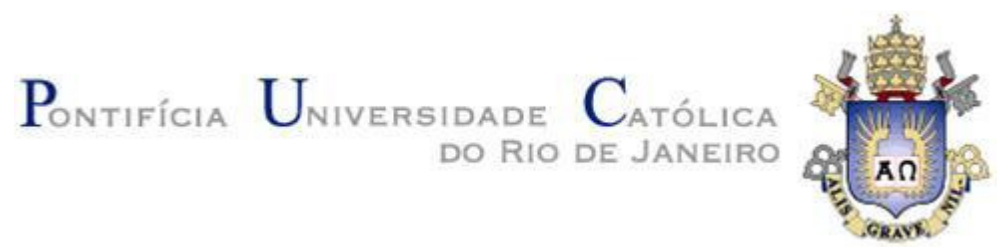

Chantal Intrator

\section{Using Scripts to Improve Web Accessibility}

Dissertation presented to the Postgraduate Program of the Departamento de Informática do Centro Técnico Científico da PUC-Rio, as partial fulfillment of the requirements for the degree of Mestre em Ciências - Informática

Prof ${ }^{\mathrm{a}}$. Clarisse Sieckenius de Souza

Advisor

Departamento de Informática - PUC-Rio

Prof. Alberto Barbosa Raposo Departamento de Informática - PUC-Rio

Prof ${ }^{a}$. Simone Bacellar Leal Ferreira Departamento de Informática Aplicada - UNIRIO

Prof. José Eugenio Leal Coordinator of the Centro Técnico Científico da PUC-Rio 
All rights reserved.

\section{Chantal Intrator}

Graduate in Computer Science from Technion-Israel Institute of Technology, in 1997. Has been working as a software developer and as a Team Leader in companies such as Intel Israel, Orkit Communications, Tioga, Quality Software, Certisign and Mundo Babel.

Bibliographic data

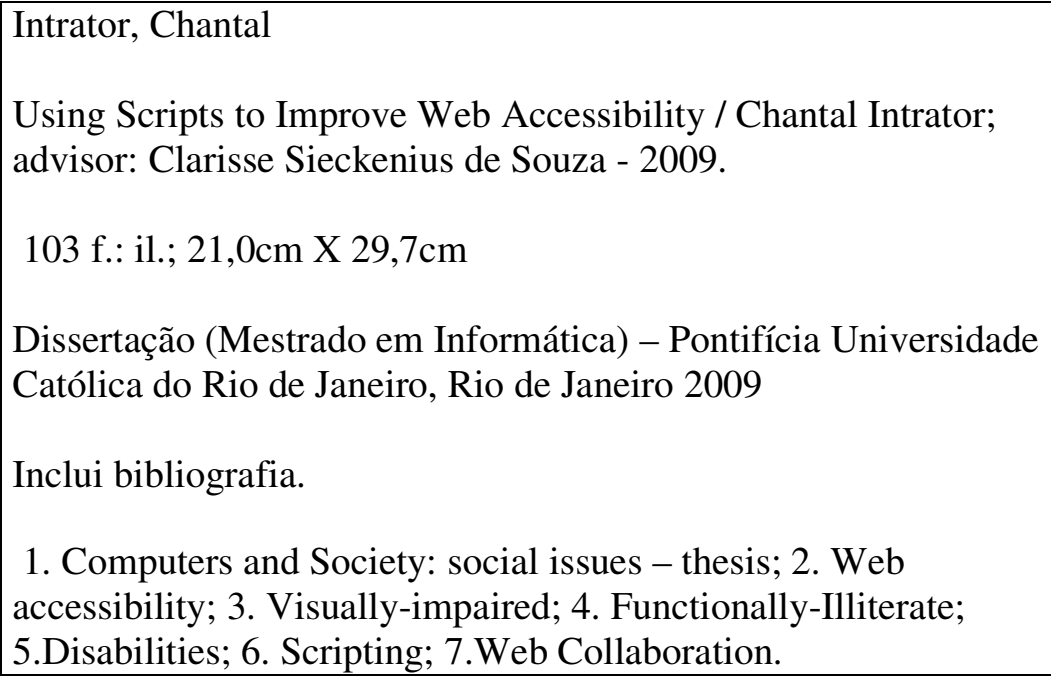

CDD: 004 


\section{Acknowledgment}

This research has, to a greater or lesser degree, been influenced by the following entities and people: Allen Cypher and the CoScripter Team at IBM Almaden Research; Ana M.B. Pavani; Ruy Luiz Milidiu and his helpful team of students; NEAD- Núcleo de Educação de Adultos; each individual user that agreed to participate in the experiments of this dissertation; my colleagues at SERG laboratory; Tiago Correa; Rubens Amaral; family and friends. I am sincerely thankful to all of them.

I am very grateful to my sweet aunt Hadara Perpignan.

Special thanks go to my always supportive and encouraging advisor Clarisse Sieckenius de Souza.

Finally, I extend all my gratitude to my adorable mom.

Chantal Intrator was partially supported by a CAPES fellowship. 


\section{Abstract}

Intrator, Chantal; de Souza, Clarisse Sieckenius. Using scripts to Improve Web Accessibility Rio de Janeiro, 2009. 103p. MSc. Dissertation Departamento de Informática, Pontifícia Universidade Católica do Rio de Janeiro.

As more and more resources become available online, the World Wide Web is turning into an important stakeholder in every individuals' lives. Nevertheless, not every segment of the distinct populations worldwide is able to freely access and use it. A new approach of navigating the web, in which users make use of automated processes created by a community of volunteers, is presented in this dissertation. The primary intent of this approach is to help blind and functionally-illiterate users in navigating the web and accessing its resources. This, though, is only the starting point for further investigations with other populations with special needs. This dissertation presents a collaborative web system, designed on top of an existing tool, for improving web accessibility.

\section{Keywords}

1. Computers and Society: social issues - thesis; 2 . Web accessibility; 3. Visually-impaired; 4. Functionally-Illiterate; 5.Disabilities; 6. Scripting; 7.Web Collaboration. 


\section{Resumo}

Intrator, Chantal; de Souza, Clarisse Sieckenius. Utilizando scripts para Melhorar a Acessibilidade na Web. Rio de Janeiro, 2009. 103p. Dissertação de Mestrado - Departamento de Informática, Pontifícia Universidade Católica do Rio de Janeiro.

À medida que mais recursos vêm sendo disponibilizados online, a Internet está se tornando um participante de grande importância na vida dos indivíduos. No entanto, nem todo segmento das distintas populações mundiais é capaz de acessá-la e usá-la livremente. Uma nova abordagem de navegação na web, na qual os usuários fazem uso de processos automáticos criados por uma comunidade de voluntários, é apresentada nesta dissertação. O primeiro objetivo desta abordagem é ajudar usuários cegos e analfabetos funcionais a navegar na web e acessar tais recursos. Isto, no entanto, é o passo inicial para futuras investigações com outros públicos de necessidades especiais. Esta dissertação apresenta um sistema web colaborativo, desenhado sobre uma ferramenta já existente, para melhorar a acessibilidade na web.

\section{Palavras-Chave}

1. Computadores e Sociedade: assuntos sociais - tese; 2. Acessibilidade na Web; 3. Deficientes Visuais; 4. Analfabetos Funcionais; 5. Deficiência; 6. Scripting; 7. Colaboração na Web. 


\section{Contents}

1 Introduction 11

1.1. Problem and Motivation 11

1.2. Purpose and Contributions 12

1.3. Outline 14

2 Users with Special Needs and Related Work 15

2.1. People with difficulty seeing web contents 15

2.1.1. Related work (helping web navigation for the blind) 17

2.1.2. Difficulties with web navigation for the blind 22

2.2. People with difficulty reading and understanding web contents 23

2.2.1. Related work (helping web navigation for the functionally-illiterate) 24

2.2.2. Difficulties with web navigation for the functionally-illiterate 26

3 WNH: Web Navigation Helper 29

3.1. CoScripter 29

3.2. Detailed Description 32

3.2.1. WNH-see and WNH-read 33

3.2.2. Differences between WNH-see and WNH-read 36

3.2.3. WNH-support 37

3.2.4. History of the project 39

3.3. Architecture 41

3.4. Illustration 46

3.4.1. Blind User Interaction 46

3.4.2. Functionally Illiterate User Interaction $\quad 50$

3.4.3. Support User Interaction 53

3.5. Error Prevention, Error Detection and Error Recovery during Interaction 56

4 The Experiment $\quad 57$

4.1. Experiments with Group 1 (alleviating sight problems) 57

4.1.1. Participants 58

4.1.2. Preparation $\quad 58$

4.1.3. Results 61 
4.1.4. Discussion $\quad 64$

4.2. Experiments with Group 2 (alleviating reading problems) 65

4.2.1. Participants 65

4.2.2. Preparation 66

4.2.3. Results 68

$\begin{array}{ll}\text { 4.2.4. Discussion } & 71\end{array}$

4.3. Difficulties evidenced during the experiments 72

5 Discussion $\quad 73$

5.1. How does WNH help or not help functionally illiterate and blind users in navigating the web? 73

5.2. How can WNH be improved to suit these two (blind and functionally illiterate) different classes of users with special needs more appropriately? 80

6 Conclusions and Future Work 82

7 Glossary

8 References 86

9 Appendix A - Consent Terms Read Aloud to the Blind 91

10 Appendix B - Experiment Scenario for the Blind 92

11 Appendix C - Consent Term for the Functionally-Illiterate 93

12 Appendix D - Experiment Scenario for the Functionally-Illiterate 94

13 Appendix E - Short Paper Presented at IHC2008 95

Note: this document was written in English since it is part of a joint project involving the SERG laboratory at PUC-Rio and the CoScripter research group at IBM Almaden Research - Human Computer Interaction Group. 


\section{List of Figures}

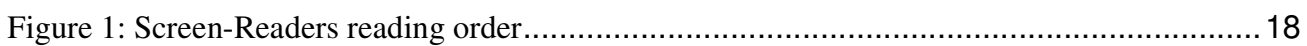

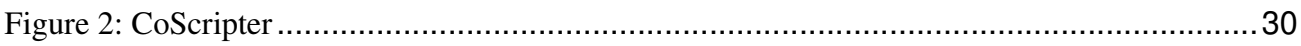

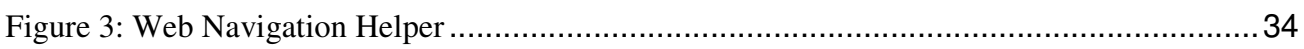

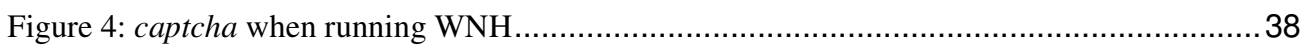

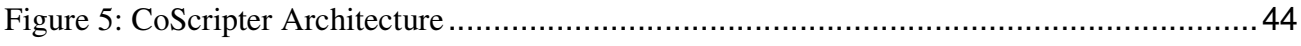

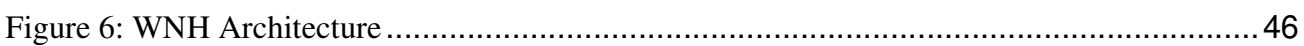

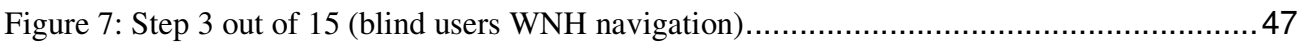

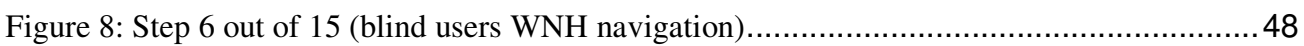

Figure 9: Step in which the CPF Id is requested (blind users WNH navigation) .....................48

Figure 10: Step that notifies of the audio captcha (blind users WNH navigation) ....................49

Figure 11: Step in which the audio captcha is being read (blind users WNH navigation) ............50

Figure 12: Step that requests the captcha (functionally illiterate users WNH navigation) ...........51

Figure 13: Step that requests the complete name (functionally illiterate users WNH navigation). 52

Figure 14: Step that informs the user to fill the birthday directly in the web page (functionally

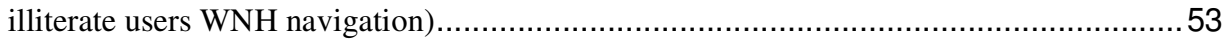

Figure 15: Volunteers' visualization of step 1 from functionally illiterate's script ...................54

Figure 16: Volunteers' visualization of captcha step from functionally illiterate's script............54

Figure 17: WNH-support Sites Tracker Bot command line execution ..................................55

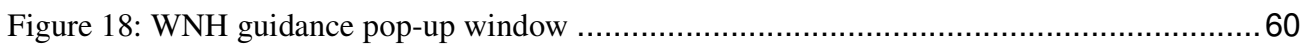

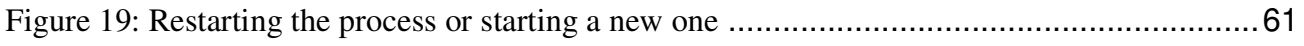

Figure 20: WNH before (A) and after (B) left sidebar information was omitted.......................67 


\section{List of Tables}

Table1 - Computer and Internet Usage According to Years of Study in Brazil 